\title{
The ancient Chinese civilization left remarkable signals in the marine environment since the Bronze Age
}

\section{Xiang Sun}

Fudan University https://orcid.org/0000-0001-7693-1125

Limin Hu ( $\square$ hulimin@fio.org.cn )

Ocean University of China

\section{Bangqi Hu}

Ocean University of China

\section{Xueshi Sun}

Fudan University

\section{Xiao Wu}

Ocean University of China

Naishuang Bi

Ocean University of China

\section{Tian Lin}

Shanghai Ocean University

\section{Zhigang Guo}

Fudan University

\section{Zuosheng Yang}

Ocean University of China

\section{Article}

Keywords: Civilization evolution in China, black carbon, soot signal, sedimentary record, Bronze Age

Posted Date: January 11th, 2021

DOl: https://doi.org/10.21203/rs.3.rs-143207/v1

License: (c) (i) This work is licensed under a Creative Commons Attribution 4.0 International License.

Read Full License 
1 The ancient Chinese civilization left remarkable signals in the marine environment since the Bronze Age

3 Xiang Sun ${ }^{1,2}$, Limin $\mathrm{Hu}^{2,3^{*}}$, Bangqi $\mathrm{Hu}^{2,4}$, Xueshi $\mathrm{Sun}^{1}$, Xiao $\mathrm{Wu}^{2,3}$, Naishuang $\mathrm{Bi}^{2,3}$,

4 Tian Lin $^{5}$, Zhigang Guo ${ }^{1,2^{*}}$, Zuosheng Yang ${ }^{3}$

$5 \quad{ }^{1}$ Department of Environmental Science and Engineering, Fudan University, Shanghai

6 200438, China

$7 \quad{ }^{2}$ Laboratory for Marine Geology, Qingdao National Laboratory for Marine Science and

8 Technology, Qingdao 266061, China

$9 \quad{ }^{3}$ Key Laboratory of Submarine Geosciences and Prospecting Techniques, Ministry of

10 Education of China, College of Marine Geosciences, Ocean University of China,

11 Qingdao 266100, China

$12{ }^{4}$ Qingdao Institute of Marine Geology, Qingdao, 266071, China

$13{ }^{5}$ College of Marine Ecology and Environment, Shanghai Ocean University, Shanghai

14 201306, China

15 Corresponding authors: hulimin@ouc.edu.cn; guozgg@fudan.edu.cn

17 Abstract

18 To understand the onset of human civilization evolution recorded in the marine

19 environment, a 6000-year record of black carbon (BC), including char and soot, was

20 examined in a sediment core from the central South Yellow Sea. The results showed

21 that the colder and drier climate dominated the variation in fire activity in northern 
22 China after mid-Holocene via decreased precipitation and vegetation cover. The char

23 released from the fire activity, can barely retrieve traces preserved in the marine

24 sediments during the civilization evolution in China since $\sim 1 \mathrm{ka}$ BP. Fortunately, the

25 soot-BC signal demonstrated that anthropogenic forces have overwhelmed the natural

26 causes of soot emission since $\sim 4 \mathrm{ka} \mathrm{BP}$ (Bronze Age) in northern China. The variation

27 in soot closely matched periods when there was large-scale use of coal or charcoal after

$28 \sim 2 \mathrm{ka} \mathrm{BP}$ and when indigenous coking technology was promoted after $\sim 1.3 \mathrm{ka} \mathrm{BP}$, and

29 times with low soot abundance coincided with periods of social unrest. This work

30 provides evidence that the soot signal could be a robust tracer for tracking the

31 civilization evolution, and the ancient Chinese civilization left remarkable soot signals

32 in the marine environment since the Bronze Age.

33 Key words: Civilization evolution in China, black carbon, soot signal, sedimentary

34 record, Bronze Age

\section{1. Introduction}

37 Industrialization is a revolutionary stage in the civilization evolution because it

38 has changed the lifestyle of human beings and brought great conveniences to human life

39 (1). However, the scale of carbon emissions since the industrial revolution have led to a

40 rise in atmospheric greenhouse gases at an unprecedented rate due to the large-scale use

41 of fossil fuels (e.g., petroleum and coal) (2), which has significantly affected the surface 
42 ecosystems (3), the atmospheric chemical composition (4), and even the regional and

43 global climate (5). The energy structures always link to the civilization evolution since

44 humans could use fire by biomass fuels as early as the middle Pleistocene $(6,7)$.

45 However, the visible trace for the onset of the ancient human civilization in the

46 environment is poorly constrained, which varies spatially over the earth and represents a

47 key piece of information to the concept of the Anthropocene (2).

48 Black carbon (BC) is a highly aromatic, recalcitrant carbon species released both

49 from the wildfire and anthropogenic fire for the main energy utilization in ancient

50 human civilization. It has two subtypes, char and soot $(8,9)$, which can be distinguished

51 by thermal optical reflectance due to their different burning temperatures $(10,11)$. BC is

52 widely distributed in lake and ocean sediments via transportation by atmospheric

53 circulation and surface runoff (12). Char particles $(1 \sim 100 \mu \mathrm{m})$ are residues of

54 combustion at temperatures of $300 \sim 600^{\circ} \mathrm{C}$ that retain some of the morphological and

55 structural features of their precursors, and are a function of biomass burning. Soot

56 particles $(<1 \mu \mathrm{m})$ are produced during high-temperature combustion $\left(>600^{\circ} \mathrm{C}\right)$, which

57 is strongly related to anthropogenic fuels (e.g., petroleum, coal, and charcoal) or high-

58 intensity biomass burning $(8,9,10,13,14,15)$. The sedimentary records of char and

59 soot can provide information for tracking past changes in fire activity forced by climate

60 change or human activities on multi-decadal to millennial scales (16). For example, the

61 char/soot ratio in sediment cores from the eastern China marginal seas was used to 
62 reconstruct the variation in the energy structures in China over the last 200 years (9),

63 and char has been used to track fire activities during the Holocene in Africa (12), the

64 Pacific Islands (17), Europe (18), and North America (19).

65 From the time when human beings use fire by biomass fuels as early as the

66 middle Pleistocene to the period of the large-scale use of fossil fuels in the industrial

67 revolution, there have been several stages in the evolution of human civilization,

68 Neolithic Age, Bronze Age, and Iron Age. Sediment cores provides striking evidence of

69 past contamination linked to the civilization evolution in various continents during

70 human history $(9,20)$. Northern China is the birthplace of Chinese civilization, which is

71 one of the oldest human civilizations. Therefore, this is a unique area for tracing

72 civilization evolution in the environment. Studies on the historical records in the

73 sedimentary strata for China have concentrated on fire activity in the large river basins

74 in southern China (20) or examined local scales $(15,21,22)$ associated with climate

75 change and human activity, while seldom on the time node of civilization evolution in

76 China.

77 The South Yellow Sea (SYS) lies in the path of the East Asian continental

78 outflow driven by the East Asian winter monsoon (EAWM). It can receive and preserve

79 large amounts of land-based materials from northern China as a natural archive via

80 atmospheric deposition and ocean current transportation (23). Therefore, this is a unique

81 and ideal place for tracing the civilization evolution in northern China. This work 
82 establishes a 6000-year high-resolution BC (char and soot) record from sediment core

83 ZY2, taken from the central SYS, to reveal the fire history of a large-scale northern

84 China since the mid-Holocene by exploring the relative importance of climate change

85 and human activity, and trace the human civilization evolution in China. This reveals

86 that the evolution of human civilization in China left remarkable signal in the marine

87 sediment since the Bronze Age.

88

89 2. Materials and Methods

90

2.1. Study area and sampling

The SYS is a semi-closed marginal sea in the western Pacific located between

92 China and the Korean Peninsula (Fig. 1). It is indirectly influenced by the Yellow and

93 Yangtze Rivers (24). Under the influence of the EAWM, the SYS is downwind of the

94 Asian continental outflow in spring and winter (25), and large amounts of land-based

95 materials are deposited in the marginal seas (26-28). Sediment core ZY2 $\left(35^{\circ} 31^{\prime} \mathrm{N}\right.$,

$96122^{\circ} 39^{\prime} \mathrm{E}$ ) was collected in the SYS at a water depth of $68.5 \mathrm{~m}$ from the R/V Dong-

97 Fang-Hong 2 in 2006. It is $342 \mathrm{~cm}$ long. The core was sampled at $1 \mathrm{~cm}$ intervals and

98 kept at $-20^{\circ} \mathrm{C}$. The lithology and chronology of the core were reported previously (24).

99 The age at the bottom of the core is $\sim 6.2 \mathrm{ka} \mathrm{BP}$, which is roughly when the modern

100 current circulation of the Yellow Sea developed (29). The homogeneous gray, dark gray 
101 clayey silt of the core promised a stable sedimentary environment with sufficient

102 sediment supply (24).

103

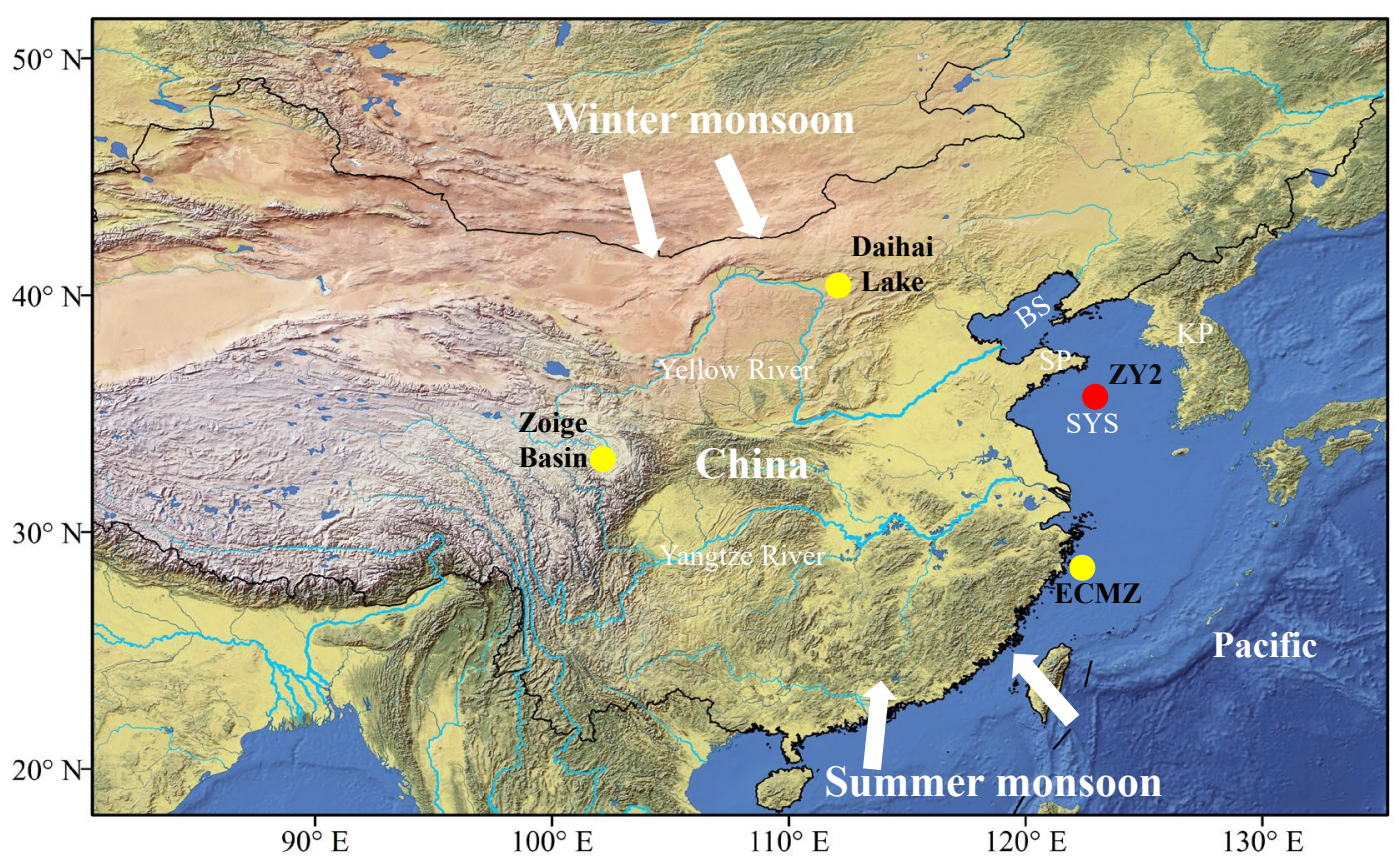

104 Fig. 1. A map showing the winter and summer monsoons, Bohai Sea (BS), South

105 Yellow Sea (SYS), Yellow and Yangtze Rivers, Pacific Ocean, Korean (KP) and

106 Shandong (SP) Peninsulas, ZY2 sediment core (red circle), and locations of fire-record

107 sediment core studied previously (yellow circles) $(20,21,22)$.

\subsection{BC analysis}

The abundance of BC was analyzed in 300 samples, at 1-cm intervals in the first

$110258 \mathrm{~cm}$ of the core and 2-cm intervals thereafter. The pretreatment method followed

111 Fang et al. (2018) (9). BC was measured at Lanzhou Institute of Arid Meteorology,

112 China Meteorological Administration using a thermal/optical carbon analyzer (DRI

113 Model 2001A; American Desert Research Institute, Reno, NV, USA), which adopted 
114 the interagency monitoring of protected visual environment (IMPROVE) protocol. To

115 begin, the analyzer oven was heated to $550^{\circ} \mathrm{C}$ in $100 \% \mathrm{He}$. This was switched to an

$116 \mathrm{O}_{2} / \mathrm{He}$ mixture $(2 \% / 98 \%)$ and the oven was heated from $550^{\circ} \mathrm{C}$ to $700^{\circ} \mathrm{C}$ and then to

$117800^{\circ} \mathrm{C}$. The gas generated with these temperature gradients was catalytically oxidized to

$118 \mathrm{CO}_{2}$ in an oxidation furnace $\left(\mathrm{MnO}_{2}\right)$, and then converted into $\mathrm{CH}_{4}$ in a reducing

119 environment. The carbon content was measured with a flame ion detector, which has

120 three peaks corresponding to organic carbon, char, and soot at three temperature stages

$121\left(550,700\right.$, and $\left.800^{\circ} \mathrm{C}\right) . \mathrm{BC}$ equals the sum of char and soot (10) and is expressed in

$122 \mathrm{mg} / \mathrm{g}$ dry sediment. Replicate analyses showed that the relative error was within 5\%,

123 and the total carbon content of the blank filter sample was below $0.05 \mathrm{mg}$.

\section{Results}

The $\mathrm{BC}$ in sediment core $\mathrm{ZY} 2$ ranged from 2.1 to $3.7 \mathrm{mg} / \mathrm{g}$ (mean $3.1 \pm 0.31$ $\mathrm{mg} / \mathrm{g} ; 1 \sigma ; \mathrm{n}=300$ ), and increased slightly from $\sim 6.2$ to $4.0 \mathrm{ka}$ BP and subsequently

128 decreased. This showed a series of centennial to multi-centennial fluctuations, with an

129 obvious decrease at $\sim 1 \mathrm{ka} \mathrm{BP}$ (Fig. 2a). The char (range $2.0-3.5 \mathrm{mg} / \mathrm{g}$, mean $3.0 \pm 0.31$

$130 \mathrm{mg} / \mathrm{g} ; 1 \sigma ; \mathrm{n}=300)$ showed a similar trend to BC (Fig. 2b). The detrend char result (Fig.

$1312 \mathrm{~d}$ ) obtained by $50 \%$ loess regression (to present the char variation on a centennial

132 timescale) showed no significant periodicity in a spectral analysis with a multi-taper

133 method and wavelet transform analysis. The strong correlation between char and $\mathrm{BC}\left(R^{2}\right.$ 
$134=0.99, P<0.01, \mathrm{n}=300)$ and the lack of a correlation $\left(R^{2}=0.020, P=0.014, \mathrm{n}=300\right)$

135 between soot and BC suggested that char is the main component of BC. The soot

136 abundance (range $0.14-0.31 \mathrm{mg} / \mathrm{g}$, mean $0.19 \pm 0.025 \mathrm{mg} / \mathrm{g} ; 1 \sigma ; \mathrm{n}=300$ ) increased

137 slightly at mid-Holocene (Fig. 2c), similar to the char variation at that time. The soot

138 abundance variation was distinct from that of char after $\sim 4 \mathrm{ka} \mathrm{BP}$, with a pronounced

139 increasing trend at $\sim 2 \mathrm{ka} \mathrm{BP}$ and a downtrend at $\sim 1.3 \mathrm{ka} \mathrm{BP}$ (Fig. 2c). 


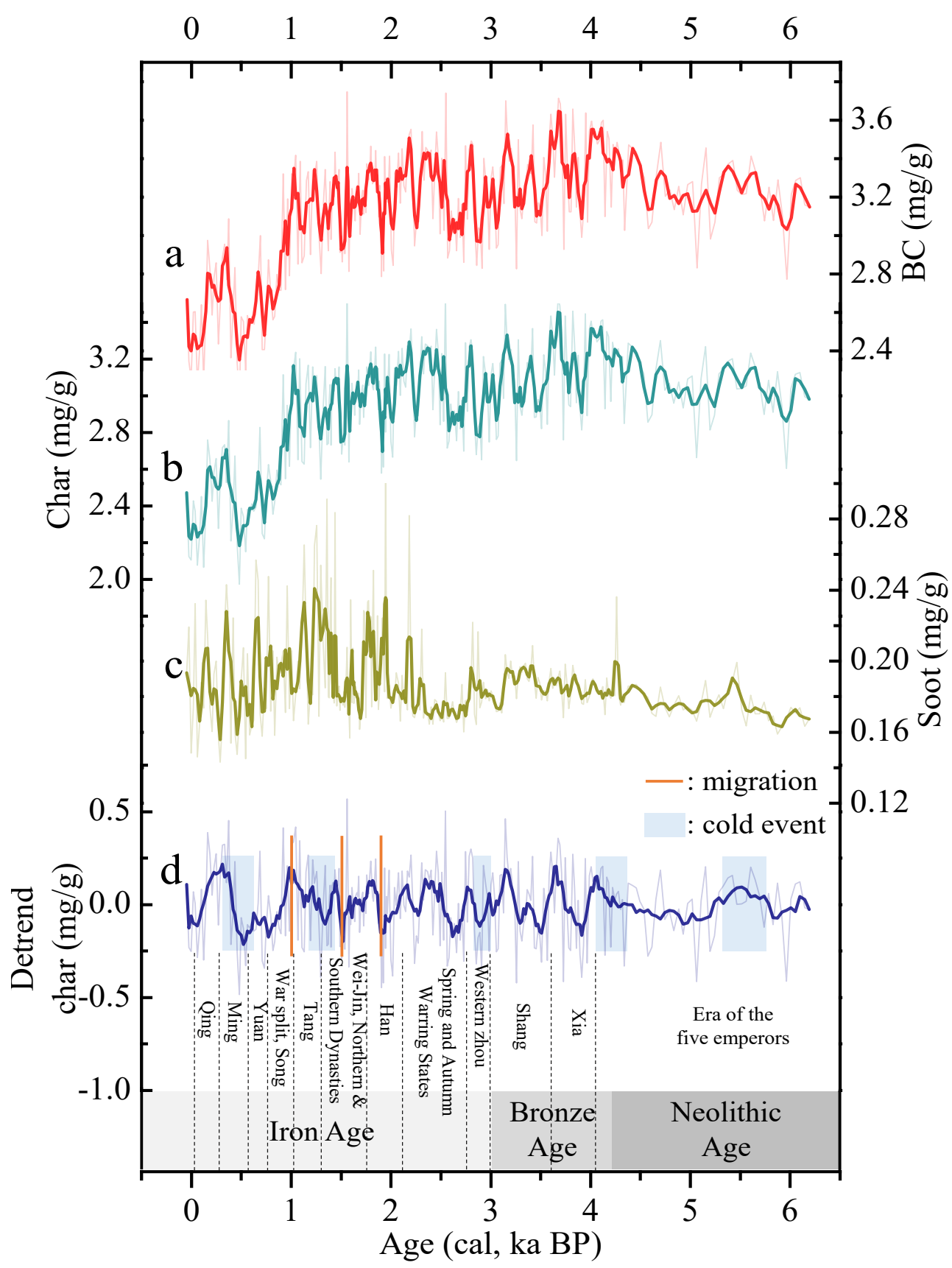

140 Fig. 2. Sediment BC data for core $\mathrm{ZY} 2$ since $\sim 6.2 \mathrm{ka} \mathrm{BP}$ : the variation in (a) BC,

141 (b) char, and (c) soot; (d) the char detrend with 50\% loess regression (Fig. S1). Signal 142 smoothing averaging three adjacent points for (a) to (c), and seven points for (d). 


\section{Discussion}

\subsection{The climate change dominated the variations of char}

The similar production processes shared by BC (including char and soot) and

146 polycyclic aromatic hydrocarbons (PAHs) could result in inference with BC sources by

147 the signatures of PAHs (30-32). The source pattern of pyrogenic high-ring PAHs in the

148 Yellow Sea sediments compared well with that of aerosol $\mathrm{PM}_{2.5}$ (i.e., particles with an

149 aerodynamic diameter $<2.5 \mu \mathrm{m}$ ) collected upwind from northern Chinese cities, Beijing

150 and Qingdao, demonstrating the significant influence of atmospheric deposition on the

151 input of combustion-derived substances into the marginal sea off northern China (25).

152 Moreover, the atmospheric deposition of $\mathrm{BC}$ contributed $\sim 51 \%$ to the total input of $\mathrm{BC}$

153 in the Bohai Sea and more than that in the SYS (23). Thus, EAMW-forced atmospheric

154 deposition played a dominant role in the BC input in the SYS. The history of the

155 EAWM intensity has been reconstructed by analyzing the sensitive grain size (24). The

156 lack of a correlation between the abundance of $\mathrm{BC}$ and grain size $\left(R^{2}=0.015, P<0.05\right.$,

$157 \mathrm{n}=300$ ) suggests that the intensity of the EAWM was not the dominant factor causing

158 the variations in $\mathrm{BC}$ (both char and soot) (char: $R^{2}=0.011, P=0.058$; soot: $R^{2}=0.068$,

$159 P<0.01)$. Additionally, the absence of a correlation between the abundance of BC and

160 the clay, silt, and sand contents suggests that the BC abundance was not influenced by

161 the dilution effects of other sediment fractions. Therefore, the sedimentary records of

162 BC in sediment core ZY2 closely reflect the emissions due to fires in northern China. 
164 consistent with char or BC records from sediment cores from the inner shelf of the East

165 China Sea (20), the Zoige Basin in the eastern Tibetan Plateau (22), and Lake Daihai in

166 north-central China $(15,21)$ (Fig. 1, Fig. S2). This suggests that the gradual weakening

167 in fire activity since the mid-Holocene is a common phenomenon across the monsoon

168 region of China. In the mid-Holocene, in the Northern Hemisphere, the earth was near

169 its perihelion in the summer, which would result in a stronger radiation (33) and a

170 greater land-ocean thermal contrast, thus increase temperature gradients, and strengthen

171 the Asian Summer Monsoon (34). With the precession cycle, the earth gradually

172 approached its apogee in summer in the Northern Hemisphere in the late Holocene (33).

173 The earth's orbit decreased summer insolation in the Northern Hemisphere (Fig. 3b)

174 (35) and induced the Asian Summer Monsoon. Oxygen isotopes are used to track past

175 summer monsoons and the precipitation intensity (36). Stalagmite $\delta^{18} \mathrm{O}$ in Dongge and

176 Sanbao Caves in China shows a gradual increase since $\sim 7 \mathrm{ka}$ BP $(36,37)$, indicating

177 gradual weakening of the precipitation since the mid-Holocene. Simultaneously, the

178 temperature (Fig. 3d) (38), moisture (Fig. 3c) (39), and vegetation cover (Fig. 3e) (40)

179 in northern China showed downward trends.

180 In general, lower temperatures are associated with decreased fire activity via

181 vegetation productivity and the incidence of fire-promoting climate conditions (41).

182 However, the char value of sediment core ZY2 unexpectedly increased slightly from 
$183 \sim 6.2$ to $4.0 \mathrm{ka}$ BP (Fig. 3a) when the climate became colder and drier. Note that fire

184 activity is not only associated with temperature but also with vegetation cover and

185 precipitation. Pollen analyses of boreholes from the Yellow River Delta showed that

186 evergreen and broadleaved deciduous forest thrived in northern China (indicated by

187 high Quercus, Carpinus/Ostrya, and Ulmus/Zelkova pollen counts) from 9.8 to $4.5 \mathrm{ka}$

188 BP in a warmer, wetter climate, and a significant reduction in deciduous Quercus pollen

189 and an increase in conifer Pinus pollen at $\sim 4$ ka BP corresponded to a drier climate (42).

190 Moreover, the percentage of tree pollen in a profile from Lake Daihai (north-central

191 China) showed a clear downward trend since the mid-Holocene (Fig. 3e) $(39,40)$.

192 Additionally, the decrease in precipitation not only affected the vegetative cover

193 (fuel abundance) but also increased its flammability (41). Fire responds differently to

194 precipitation and depends on whether vegetation cover (fuel abundance) is initially a

195 factor limiting fire spread. In arid and semi-arid environments, increases in precipitation

196 tend to increase fires (43), whereas increased precipitation reduces fire activity in humid

197 environments (44). Therefore, the unexpected increase in fire activity from $\sim 6.2$ to 4.0

198 ka BP could be attributed to a threshold effect of precipitation and vegetation cover on

199 fire activity. Specifically, in the mid-Holocene, when northern China had a humid

200 environment and vegetation cover (fuel abundance) was not a factor limiting fire spread,

201 decreases in precipitation could enhance the flammability of vegetation and increase fire

202 activity. Subsequently, as precipitation continued to decrease, the amount of vegetation 
203 decreased and limited fire propagation. This induced the decrease in fire activity with

204 the continuous reduction in precipitation and vegetation since $\sim 4$ ka BP (Fig. 3a).

Although the millennial-scale, large-area decrease in fire activity in northern

206 China since $\sim 4$ ka BP can be explained by the natural climate dynamics (45), the

207 evolution of human civilization should not be ignored in this process (46). The

208 Zhoukoudian archaeological discovery illustrated that Beijingers had the ability to

209 control fire behavior as early as the middle Pleistocene (7). Since then, fire has been

210 used for heating, lighting, cooking, driving beasts, living in groups, and making and

211 creating new living materials (47). The Yellow River Basin in northern China is the

212 origin of the ancient Chinese civilization and millet agriculture. Millet agriculture was

213 developed in the pre-Yangshao Period (8.5 7 ka BP) (48), and fire has been used to

214 clear forest for cultivation and settlement since $\sim 7.7 \mathrm{ka}$ BP in China (47). Subsequently,

215 millet agriculture developed rapidly in the Yellow River Basin (49). The number of

216 archaeological sites in northern China increased substantially after $\sim 7$ ka BP and even

217 more markedly between $\sim 4.5$ and $3 \mathrm{ka} \mathrm{BP}$ (Fig. 3f) (50). However, the number of

218 archaeological sites in northern China declined sharply at $\sim 3 \mathrm{ka} \mathrm{BP}$, which may be

219 related to climate change and the growth characteristics of millet, which is a drought-

220 tolerant crop that is sensitive to temperature change (48). The gradually weakened

221 insolation and decreased temperature in the Northern Hemisphere is not always

222 conducive to millet cultivation. The decrease in archaeological sites after $\sim 3$ ka BP (Fig. 
3f) corresponded to a major shift in the subsistence economy from predominantly

224 animal husbandry and plant cultivation to mobile pastoralism across present-day

225 semiarid northern China, which left fewer traces in the archaeological records than

226 sedentary communities (51). This variation in human activity (number of archaeological

227 sites) was not recorded by the char in core ZY2, suggesting that climate change was the

228 dominant factor affecting fires on a millennial-scale over a large area, rather than human

229 activity. However, there has a more pronounced decrease in fire activity at $\sim 1 \mathrm{ka}$ BP

230 (Fig. 3a), when a semi-pastoral, semi-agricultural economy was established in northern

231 China to accommodate the cold-dry climate (52), and fire management was used to

232 prevent uncontrolled wildfires to limit damage to settlements and agricultural resources

233 (53), which might have led to the obvious decrease in fire activity at $\sim 1$ ka BP.

234 The record of fire based on char in core ZY2 also showed a series of centennial

235 to multi-centennial fluctuations (Fig. 2d). The North Atlantic cold events (5.5, 4.2, 2.8,

236 1.4, and $0.4 \mathrm{ka} \mathrm{BP})$ during the mid-late-Holocene $(54,55)$ were large-scale phenomena

237 rather than local ones (56). Most of them could be attributed to weakening solar

238 activity, which in turn affected the ocean and atmospheric circulation on earth, causing

239 abrupt climate change $(57,58)$. The period of abrupt change corresponds to the

240 variation in the Holocene Asian Summer Monsoon (36), which could have affected the

241 fire activity in northern China. The detrend char records showed that the 5.5 and $4.2 \mathrm{ka}$

242 BP cold events coincided with episodes of high fire activity; while the cold events of 
244 (Fig. 2d). This means that the threshold effect (as discussed above) of climate change on

245 fire activity could also partly explain the centennial fluctuations in fire in northern

246 China, suggesting that the cold events before $\sim 4$ ka BP promoted fire activity, while

247 subsequent cold events decreased the fire activity.

The paleoclimatic and archaeological evidence suggests that the abrupt droughts and cold climate resulted in warfare, population migration, and dynasty change (59). This is especially true for northern China, where society was more sensitive to severe climatic conditions due to the relatively high latitudes (60). There were three large population migrations from northern to southern China during 1.9-1.8 ka BP (late Han Dynasty), 1.6-1.4 ka BP (Wei-Jin Southern \& Northern Dynasties), and 1.1-0.9 ka BP (Tang-Song Dynasty) (61). The reduction in the population of northern China generally reduced the intensity of human activity, which decreased fire activities (20). The migrations in 1.9-1.8 and 1.6-1.4 ka BP coincided with low fire activity (Fig. 2d); while the migration in 1.1-0.9 ka BP coincided with high fire activity (Fig. 2d). The

258 Tang-Song period occurred during the Medieval Warm Period, which likely

259 overwhelmed the population reduction in northern China and dominated fire occurrence 260 in this period. Different spatial scales have different fire regimes. The climate-vegetation

262 relationship can generally drive both global and sub-continental fire regimes, while 
263 human-induced fires are prominent mainly on a local scale (62-64). Small-scale human

264 activity can affect natural fire regimes, even in pyrogeographic settings in which climate

265 exerts strong, top-down controls on fuel (65). Fortunately, muddy shelf areas may

266 contain an integrated burning imprint of the mainland, which avoids the influence of

267 small-scale human activities on local fires. The discussion above means that variations

268 of char are dominated by climate change, both on the millennium timescale and the

269 centennial timescale. Even if the obvious decrease in fire activity at $\sim 1$ ka BP could

270 attribute to the establishment of the semi-pastoral, semi-agricultural economy and the

271 fire management in northern China, it was ultimately associated with the cold-dry

272 climate. Therefore, char can barely retrieve traces left in the environment during the

273 civilization evolution in China. 


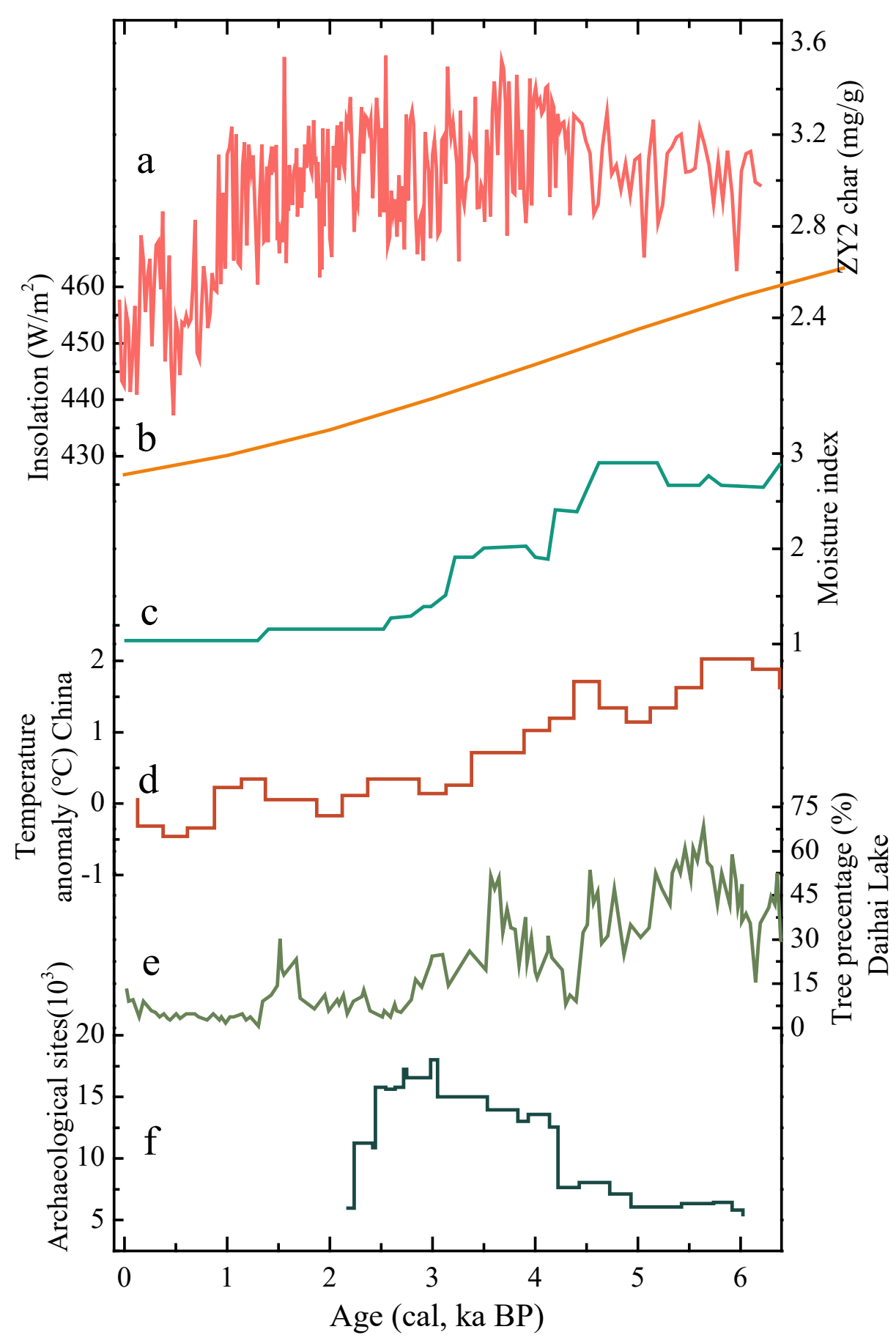

274 Fig. 3. Comparison of the millennial-timescale variation in BC records from ZY2 with 275 other records since $6.2 \mathrm{ka} \mathrm{BP}$. (a) Fire activities recorded by char from core ZY2 in the 276 SYS (this study); (b) extraterrestrial insolation of mid-month insolation $65 \mathrm{~N}$ for July 277 (33); (c) moisture index-based pollen in northern China (39); (d) temperature anomaly 278 in China (38); (e) percentage of tree pollen recorded from the sediment core in Lake 279 Daihai (40); (f) change in the total number of archaeological sites in northern China 280 from 6 to $2 \mathrm{ka} \mathrm{BP}(50)$. 
The soot abundance increased slightly during the mid-Holocene (Fig. 2c),

similar to the char variation at that time. The correlation between soot and char at $4 \sim 6.2$ ka BP was significant (Fig. $4 \mathrm{a} ; R^{2}=0.46, P<0.01, \mathrm{n}=58$; removing two outliers, Fig.

$\mathrm{S} 3)$. Soot is produced via high-temperature $\left(>600^{\circ} \mathrm{C}\right)$ gas-to-particle conversion under dry conditions and can reflects high-intensity biomass burning and is generated with char (14). Therefore, the slight increase in soot during the mid-Holocene could be predominantly attributed to natural factors. However, the correlation between soot and 290 char decreased during 3 4 ka BP (Fig. 4b; $R^{2}=0.33, P<0.01, \mathrm{n}=60$ ) and showed no 291 correlation after $\sim 3 \mathrm{ka} \mathrm{BP}$ (Fig. 4f), suggesting the influence of anthropogenic factors 292 on soot emission. Besides release from high-intensity biomass burning, soot can be 293 generated from the combustion of fuel (e.g., petroleum, coal, and charcoal) $(13,14)$.

294 Although the Hou Hanshu, a famous Chinese historical document about the Han

295 Dynasty, indicates that China first collected and used petroleum in the Wei-Jin, 296 Southern \& Northern Dynasties (1730-1369 BP), petroleum was not used widely (66).

297 However, China has long used coal and charcoal as an important source of energy (67). years ago, when China entered the Bronze Age. Bronze is an alloy of copper and tin or lead. Its melting point is between 700 and $900^{\circ} \mathrm{C}$, which exceeds the production 
301 temperature of soot $\left(>600^{\circ} \mathrm{C}\right)$. At that time, charcoal and bamboo charcoal were the

302 major fuels for smelting bronze (68). At smelting temperatures, charcoal fuel promoted

303 soot production, which caused the increase in soot during 3 4 ka BP (Fig. 4g). The

304 anthropogenic soot emissions reduced the correlation between soot and char during 3 4

305 ka BP (Fig. 4f).

306 China entered the Iron Age during the Western Zhou Dynasty ( $\sim 3$ ka BP). The

307 smelting temperature of iron is about $1500^{\circ} \mathrm{C}$, meaning that more fuel is used for

308 smelting (68). During the Iron Age, soot and char were not correlated, suggesting that

309 anthropogenic factors dominated soot emission. Soot abundance increased at $\sim 2 \mathrm{ka}$ BP

310 (Fig. 4g), corresponding to the Han Dynasty (2156-1730 BP), when coal and charcoal

311 fuel began to be used for large-scale metal smelting and agricultural tool production (67,

312 68). The Song Dynasty (990-671 BP) started a national coal monopoly, and coal

313 became an important resource related to the national economy and people's livelihoods

314 during the Ming and Qing Dynasties (582-39 BP) $(67,69)$. However, soot abundance

315 decreased beginning in $\sim 1.3 \mathrm{ka} \mathrm{BP}$ (Fig. 4g), when indigenous coking technology was

316 developed (70). In the Tang Dynasty (1332-1043 BP), coke was in its embryonic stage.

317 By the Song Dynasty (990-671 BP), coking technology had matured and coke ovens

318 were studied in archeology (70). In indigenous coking technology, a kiln with an

319 ignition hole in the side wall is used to ignite the coking coal stacked in the kiln. This 
320 suggests that the application of indigenous coking technology reduced the emission of

321 soot compared with the direct combustion of raw coal.

322 China underwent several dynasty changes and united and split after the Xia

323 Dynasty (4096 3625 BP). The Spring and Autumn Waring States (2721-2171 BP),

324 Wei-Jin Southern \& Northern Dynasties (1730-1369 BP), and Five Dynasties \& Ten

325 Kingdoms (1043-971 BP) periods were the three main splits in Chinese history,

326 corresponding to the main three valleys in soot abundance at $\sim 2.5, \sim 1.5$, and $\sim 0.8 \mathrm{ka}$ BP

327 (Fig. 4g). Periods with low soot abundance generally coincided with dynasty changes

328 (Fig. 4g), when there were more wars. During periods of social stability, coal and

329 charcoal were the main energy source for agricultural tool and handicraft production,

330 metal smelting, and heating (68). Wars led to social unrest and the displacement of

331 people, reducing soot emissions from coal and charcoal use in people's daily lives. 

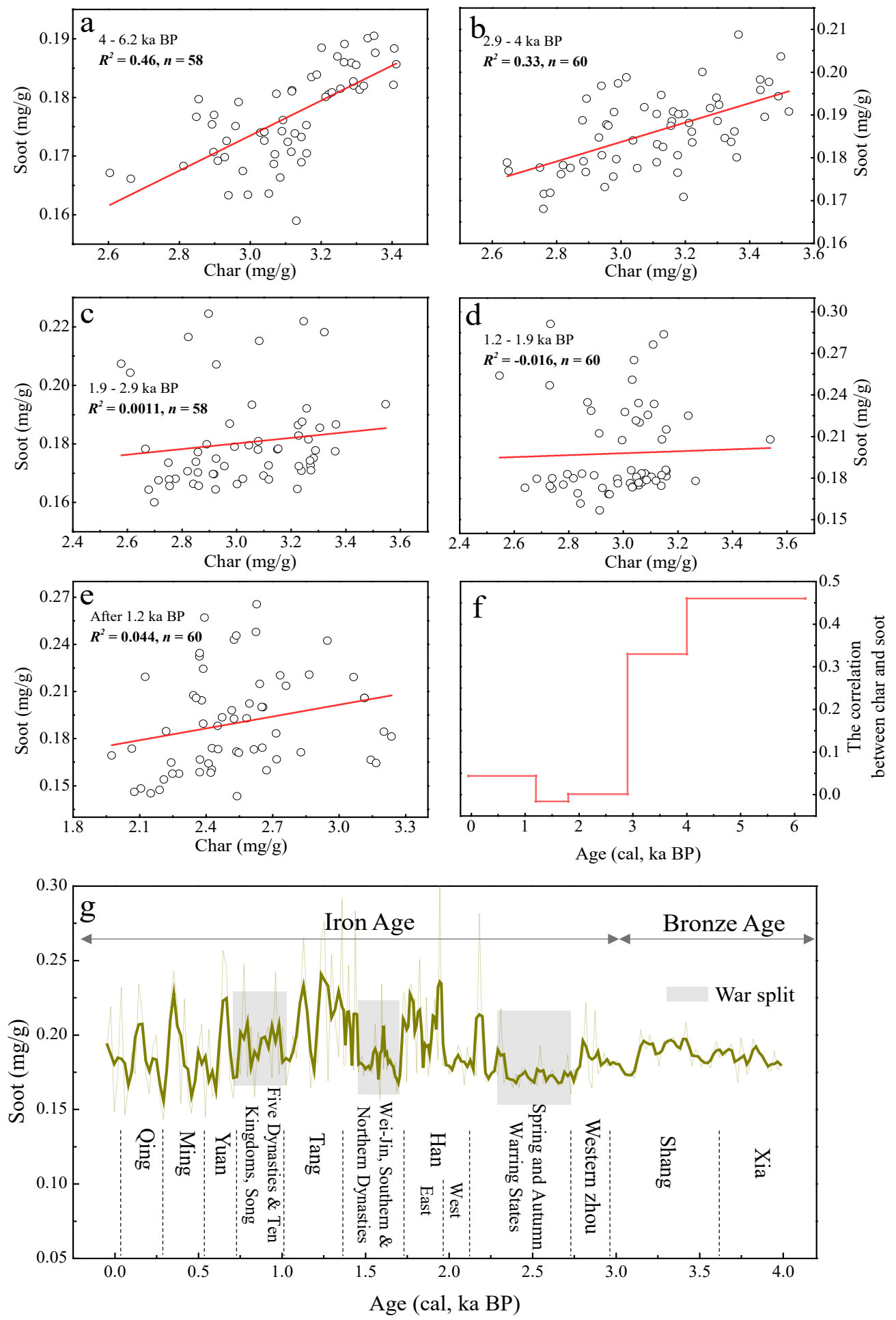

332 Fig. 4. (a) to (e) show the correlations between char and soot at 0.05-1.2, 1.2-1.88, 333 1.88-2.9, 2.9-4, and, 4-6.2 ka BP, respectively. (f) Change in the correlation between 334 char and soot since $\sim 6.2 \mathrm{ka} \mathrm{BP}$; ( $\mathrm{g}$ ) changes in soot from 0 to $4 \mathrm{ka} \mathrm{BP}$ and the 335 corresponding Chinese dynasties; signal smoothing was performed by averaging three 336 adjacent points. 


\section{Conclusions and Implications}

The char-BC record revealed that the colder, drier climate before $\sim 4 \mathrm{ka} \mathrm{BP}$

339 enhanced the fire activity slightly; this was followed by an obvious reduction in fire

340 activity. The decoupling between climate change and fire occurrence suggested that the

341 climate-induced precipitation and vegetation cover had a threshold effect on the fire

342 regime. The synergistic effect of human activity and climate change resulted in a

343 significant decline in fire $\sim 1 \mathrm{ka}$ BP. Ultimately, the climate dominated the variation in

344 fire activity in northern China both on the millennium timescale and the centennial

345 timescale, therefore the char can barely retrieve traces persevered in the marine

346 environment during the civilization evolution in China. However, the variation in soot

347 clearly marked the large-scale use of coal and charcoal since $\sim 2$ ka BP (Han Dynasty)

348 and adoption of indigenous coking technology after $\sim 1.3 \mathrm{ka}$ BP (Tang Dynasty), which

349 is consistent with historical documents and archaeological discoveries. Periods of social

350 unrest in the cold weapon era coincided with the low soot abundance, suggesting that

351 wars reduced in soot emission from coal and charcoal use in people's daily lives. The

352 soot signal demonstrated that anthropogenic forces overwhelmed natural factors as the

353 cause of soot emissions after $\sim 4 \mathrm{ka} \mathrm{BP}$ (Bronze Age) in northern China. The time node

354 represents a key piece of information to establish the natural background of soot-BC in

355 the marine sediments and to specify the concept of the Anthropocene. 
358 Acknowledgments

359 This work was supported by the National Natural Science Foundation of China (NSFC)

360 (Nos.: 41676034 and 41722603), the National Key Research and Development Program

361 of China (No: 2016YFA0601903) and in part by the Taishan Scholar Program

362 (TSQN20182117).

363

364 The English in this document has been checked by at least two professional editors, both

365 native speakers of English. For a certificate, please see:

366 http://www.textcheck.com/certificate/YRNO5t

367

368 References:

369 1. S. Lall, Technological capabilities and industrialization. World Development 20, 165-

$370186(1992)$.

371 2. A. Glikson, Fire and human evolution: The deep-time blueprints of the

372 Anthropocene. Anthropocene 3, 89-92 (2013).

373 3. B. Bond-Lamberty, S. D. Peckham, D. E. Ahl, S. T. Gower, Fire as the dominant

374 driver of central Canadian boreal forest carbon balance. Nature 450, 89-90 (2007).

375 4. F. Justino, W. R. Peltier, H. A. Barbosa, Atmospheric susceptibility to wildfire

376 occurrence during the Last Glacial Maximum and mid-Holocene. Palaeogeography

377 Palaeoclimatology Palaeoecology 295, 76-88 (2010). 
378 5. M. J. S. B. David et al., Fire in the earth system. Science 324, 481-484 (2009).

379 6. J. R. Marlon et al., Global biomass burning: a synthesis and review of Holocene

380 paleofire records and their controls. Quaternary Science Reviews 65, 5-25 (2013).

381 7. S. Weiner, Q. Xu, P. Goldberg, J. Liu, O. Bar-Yosef, Evidence for the Use of Fire at

382 Zhoukoudian, China. Science 281, 251-253 (1998).

383 8. M. Elmquist, G. Cornelissen, Z. Kukulska, O. Gustafsson, Distinct oxidative

384 stabilities of char versus soot black carbon: Implications for quantification and

385 environmental recalcitrance. Global Biogeochemical Cycles 20, GB20092 (2006).

386 9. Y. Fang et al., Spatiotemporal trends of elemental carbon and char/soot ratios in five

387 sediment cores from eastern China marginal seas: Indicators of anthropogenic activities

388 and transport patterns. Environmental Science \& Technology 52, 9704-9712 (2018).

389 10. Y. M. Han et al., Evaluation of the thermal/optical reflectance method for

390 discrimination between char- and soot-EC. Chemosphere 69, 569-574 (2007).

391 11. C. Santin, S. H. Doerr, C. M. Preston, G. Gonzalez-Rodriguez, Pyrogenic organic

392 matter production from wildfires: a missing sink in the global carbon cycle. Global

393 Change Biology 21, 1621-1633 (2015).

394 12. M. I. Bird, J. A. Cali, A million-year record of fire in sub-Saharan Africa. Nature 395 394, 767-769 (1998).

396 13. Y. M. Han et al., Asian inland wildfires driven by glacial-interglacial climate

397 change. Proceedings of the National Academy of Sciences 117, 5184-5189 (2020). 
14. Y. M. Han et al., Climate and fuel controls on north American paleofires:

399 Smoldering to flaming in the late-glacial-Holocene transition. Science Reports 6, 20719 $400 \quad(2016)$

401 15. Y. M. Han, J. R. Marlon, J. J. Cao, Z. D. Jin, Z. S. An, Holocene linkages between 402 char, soot, biomass burning and climate from Lake Daihai, China. Global

403 Biogeochemical Cycles 26, GB4017 (2012).

404 16. V. Iglesias, C. Whitlock, Fire responses to postglacial climate change and human 405 impact in northern Patagonia $\left(41-43^{\circ} \mathrm{S}\right)$. Proceedings of the National Academy of 406 Sciences 111, 5545-5554 (2014).

407 17. D. B. McWethy et al., Rapid landscape transformation in South Island, New 408 Zealand, following initial Polynesian settlement. Proceedings of the National Academy 409 of Sciences 107, 21343-21348 (2010).

410 18. F. Olsson, M. Gaillard-Lemdahl, G. Lemdahl, A. Eklund, P. Lanos, Holocene forest

411 fires in the hemiboreal zone of southern Sweden 10,500 calendar years BP to modern

412 time: The role of climate and human activities. Paleogeography, Paleoclimatology,

413 Paleoecology 291, 128-141 (2010).

414 19. C. Carcaillet, P. J. H. Richard, H. Asnong, L. Capece, Y. Bergeron, Fire and soil 415 erosion history in East Canadian boreal and temperate forests. Quaternary Science 416 Reviews 25, 1489-1500 (2006). 
417 20. W. Pei et al., Human impact overwhelms long-term climate control of fire in the

418 Yangtze River Basin since 3.0 ka BP. Quaternary Science Reviews 230, 106165 (2020).

419 21. X. Wang, J. Xiao, L. Cui, Z. Ding, Holocene changes in fire frequency in the Daihai

420 Lake region (north-central China): indications and implications for an important role of

421 human activity. Quaternary Science Reviews 59, 18-29 (2013).

422 22. W. Zhao, Y. Zhao, F. Qin, Holocene fire, vegetation, and climate dynamics inferred 423 from charcoal and pollen record in the eastern Tibetan Plateau. Journal of Asian Earth

424 Sciences 147, 9-16 (2017).

425 23. Y. Fang et al., Flux and budget of BC in the continental shelf seas adjacent to

426 Chinese high BC emission source regions. Global Biogeochemical Cycles 29, 957-972 427 (2015).

428 24. B. Hu et al., Grain size records reveal variability of the East Asian Winter Monsoon 429 since the Middle Holocene in the Central Yellow Sea mud area, China. Science China430 earth Sciences 55, 1656-1668 (2012).

$43125 . T$. Lin et al., Sources of polycyclic aromatic hydrocarbons to sediments of the Bohai 432 and Yellow Seas in East Asia. Journal of Geophysical Research: Atmospheres 116, 433 D23305 (2011).

434 26. J. M. Martin, J. Zhang, M. C. Shi, Q. Zhou, Actual flux of the huanghe (Yellow435 river) sediment to the western Pacific-ocean. Netherlands Journal of Sea Research 31, $436 \quad 243-254(1993)$. 
437 27. J. D. Milliman, Y. S. Qin, M. E. Ren, Y. Saito, Mans influence on the erosion and 438 transport of sediment by asian rivers - the Yellow-river (Huanhe) example. Journal of 439 Geology 95, 751-762 (1987).

440 28. C. R. Alexander, D. J. Demaster, C. A. Nittrouer, Sediment Accumulation in a 441 modern epicontinental-shelf setting - the yellow sea. Marine Geology 98, 51-72 (1991). 442 29. J. M. Kim, M. Kucera, Benthic foraminifer record of environmental changes in the 443 Yellow Sea (Hwanghae) during the last 15,000 years. Quaternary Science Reviews 19, $444 \quad 1067-1085(2000)$.

445 30. Y. M. Han et al., Comparison of elemental carbon in lake sediments measured by 446 three different methods and 150-year pollution history in eastern China. Environmental 447 Science \& Technology 45, 5287-5293 (2011).

448 31. Y. M. Han et al., Stronger association of polycyclic aromatic hydrocarbons with 449 soot than with char in soils and sediments. Chemosphere 119, 1335-1345 (2015). 450 32. Y. Fang et al., Application of PMF receptor model merging with PAHs signatures 451 for source apportionment of black carbon in the continental shelf surface sediments of 452 the Bohai and Yellow Seas, China. Journal of Geophysical Research: Oceans 121, 453 1346-1359 (2016).

454 33. A. Berger, M. F. Louter, Insolation values for the climate of the last 10000000 455 years. Quaternary Science Reviews 10, 297-317 (1991). 
34. J. E. Kutzbach, Climatic changes of the last 18,000 years - observations and model

457 simulations. Science 241, 1043-1052 (1988).

458 35. A. K. Gupta, D. M. Anderson, J. T. Overpeck, Abrupt changes in the Asian

459 southwest monsoon during the Holocene and their links to the North Atlantic Ocean.

$460 \quad$ Nature 421, 354-357 (2003).

461 36. Y. Wang et al., The Holocene Asian Monsoon: links to solar changes and North

462 Atlantic climate. Science 308, 854-857 (2005).

463 37. Y. Wang et al., Millennial- and orbital-scale changes in the East Asian monsoon

464 over the past 224,000 years. Nature 451, 1090-1093 (2008).

465 38. S. Wang, D. Gong, J. Zhu, Twentieth-century climatic warming in China in the

466 context of the Holocene. Holocene 11, 313-321 (2001).

467 39. Y. Zhao, Z. Yu, F. Chen, J. Zhang, B. Yang, Vegetation response to Holocene

468 climate change in monsoon-influenced region of China. Earth-Science Reviews 97, $469 \quad 242-256(2009)$.

470 40. J. Xiao, Q. Xu, T. Nakamura, X. Yang, W. Liang, Y. Inouchi, Holocene vegetation

471 variation in the Daihai Lake region of north-central China: a direct indication of the

472 Asian monsoon climatic history. Quaternary Science Reviews 23, 1669-1679 (2004).

473 41. A. L. Daniau et al., Predictability of biomass burning in response to climate

474 changes. Global Biogeochemical Cycles 26, GB4007 (2012). 
476 inferred from pollen assemblages in the Huanghe (Yellow River) delta, China: climatic

477 change and human impact. Quaternary Science Reviews 22, 609-628 (2003). Colorado front range, U.S.A., and the northern Patagonian Andes, Argentina. Plant Ecology 163, 187-207 (2002).

44. M. A. Krawchuk, M. A. Moritz, Constraints on global fire activity vary across a 482 resource gradient. Ecology 92, 121-132 (2011). modeled and reconstructed changes in forest cover through the past 8000 years:

485 Eurasian perspective. The Holocene 21, 723-734 (2011).

46. F. H. Chen et al., Asian dust-storm activity dominated by Chinese dynasty changes since 2000 BP. Nature Communications 11, 992 (2020).

47. Y. Zong et al., Fire and flood management of coastal swamp enabled first rice paddy

489 cultivation in east China. Nature 449, 459-U4 (2007).

490 48. X. Yang et al., Early millet use in northern China. Proceedings of the National 491 Academy of Sciences 109, 3726-3730 (2012).

492 49. G. Dong, S. Zhang, Y. Yang, J. Chen, F. Chen, Agriculture intensification and its 493 impact on the environment in the Neolithic Age of northern China. Scientific Bulletin 494 (in Chinese) 61, 2913-2925 (2016). 
50. M. Wagner et al., Mapping of the spatial and temporal distribution of archaeological

496 sites of northern China during the Neolithic and Bronze Age. Quaternary International 497 290, 344-357 (2013).

498 51. M. Wagner et al., Radiocarbon-dated archaeological record of early first millennium

499 BC mounted pastoralists in the Kunlun Mountains, China. Proceedings of the National

500 Academy of Sciences 108, 15733-15738 (2011).

501 52. Z. H. Tan, C. C. Huang, J. L. Pang, Q. Y. Zhou, Charcoal recorded Holocene fire

502 history in the northern part of the Longdong Loess Plateau. Quaternary Sciences (in

503 Chinese) 28, 733-738 (2008).

504 53. J. B. Iriartea et al., Fire-free land use in pre-1492 Amazonian savannas. Proceedings

505 of the National Academy of Sciences 109, 6473-6478 (2012).

506 54. M. Moros et al., Sea surface temperatures and ice rafting in the Holocene North

507 Atlantic: climate influences on Northern Europe and Greenland. Quaternary Science

508 Reviews 23, 2113-2126 (2004).

509 55. B. Risebrobakken, E. Jansen, C. Andersson, E. Mjelde, K. Hevroy, A high-

510 resolution study of Holocene paleoclimatic and paleoceanographic changes in the

511 Nordic Seas. Paleoceanography 18, 10171 (2003).

512 56. G. Bond et al., A pervasive millennial-scale cycle in North Atlantic Holocene and

513 glacial climates. Science 278, 1257-1266 (1997). 
514 57. H. Goosse, H. Renssen, F. M. Selten, R. J. Haarsma, J. D. Opsteegh, Potential

515 causes of abrupt climate events: A numerical study with a three-dimensional climate

516 model. Geophysical Research Letters 29, 7-1-7-4 (2002).

517 58. M. Stuiver et al., INTCAL98 radiocarbon age calibration, 24,000-0 cal BP.

518 Radiocarbon 40, 1041-1083 (1998).

519 59. P. Zhang et al., A Test of Climate, Sun, and Culture Relationships from an 1810-

520 Year Chinese Cave Record. Science 322, 940-942 (2008).

521 60. Q. Pei, D. D. Zhang, H. F. Lee, Contextualizing human migration in different agro-

522 ecological zones in ancient China. Quaternary International 426, 65-74 (2016).

523 61. J. Ge, History of Chinese Population, Fudan University Press (in Chinese), Volumes

$524 \quad 1-3(2002)$.

525 62. E. Dietze et al., Holocene fire activity during low-natural flammability periods

526 reveals scale-dependent cultural human-fire relationships in Europe. Quaternary Science

527 Reviews 201, 44-56 (2018).

528 63. O. Pechony, D. T. Shindell, Driving forces of global wildfires over the past

529 millennium and the forthcoming century. Proceedings of the National Academy of

530 Sciences 107, 19167-19170 (2010).

531 64. V. A. Carter et al., Holocene-scale fire dynamics of central European temperate

532 spruce-beech forests. Quaternary Science Reviews 191, 15-30 (2018). 
533 65. C. I. Roos, M. N. Zedeño, K. L. Hollenback, M. M. H. Erlick, Indigenous impacts

534 on North American Great Plains fire regimes of the past millennium. Proceedings of the

535 National Academy of Sciences 115, 8143-8148 (2018).

536 66. Y. Fan, Houhanshu, Zhonghua Book Company (in Chinese), Volumes 19-23 (445).

537 67. China Coal Journal Editorial Committee, China Coal Journal: Comprehensive

538 Volume. Coal Publishing House (Beijing), Volumes 1-20 (1999).

539 68. J. Hua, Ancient Chinese metal technology: Copper and iron civilization, Elephant

540 Press (in Chinese), 32-318 (1999).

541 69. D. Zhao, General History of Chinese Economy, Hunan Press (in Chinese), Volumes

$542 \quad 1-8(2002)$.

543 70. X. Wu, The basic context of the history of ancient coal mines in China and the main

544 features of coal development and utilization. Journal of China University of Mining and

545 Technology - Social Science Edition (in Chinese) 12, 91-98 (2010).

546

547 
Figures

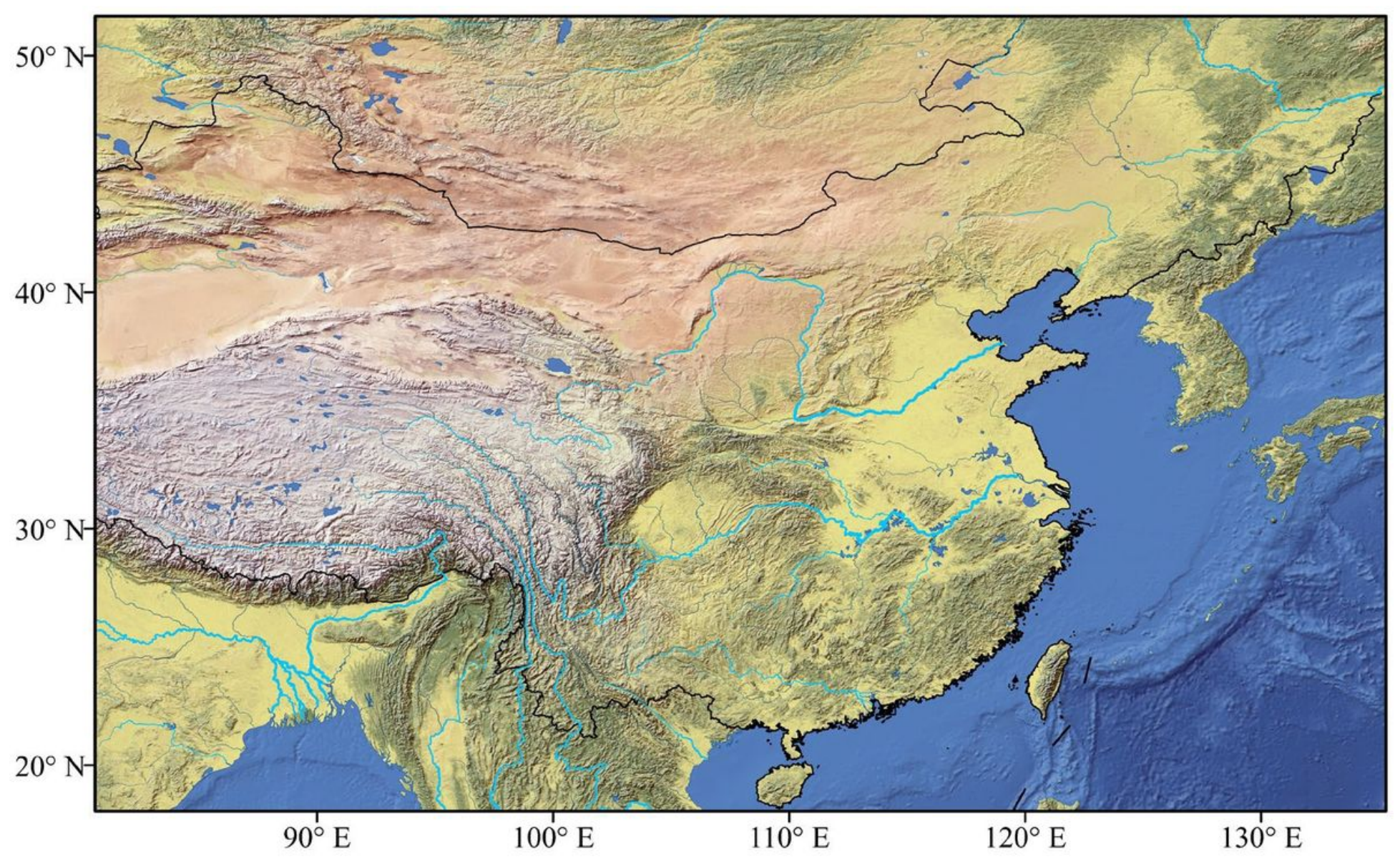

Figure 1

A map showing the winter and summer monsoons, Bohai Sea (BS), South Yellow Sea (SYS), Yellow and Yangtze Rivers, Pacific Ocean, Korean (KP) and Shandong (SP) Peninsulas, ZY2 sediment core (red circle), and locations of fire-record sediment core studied previously (yellow circles) $(20,21,22)$. Note: The designations employed and the presentation of the material on this map do not imply the expression of any opinion whatsoever on the part of Research Square concerning the legal status of any country, territory, city or area or of its authorities, or concerning the delimitation of its frontiers or boundaries. This map has been provided by the authors. 


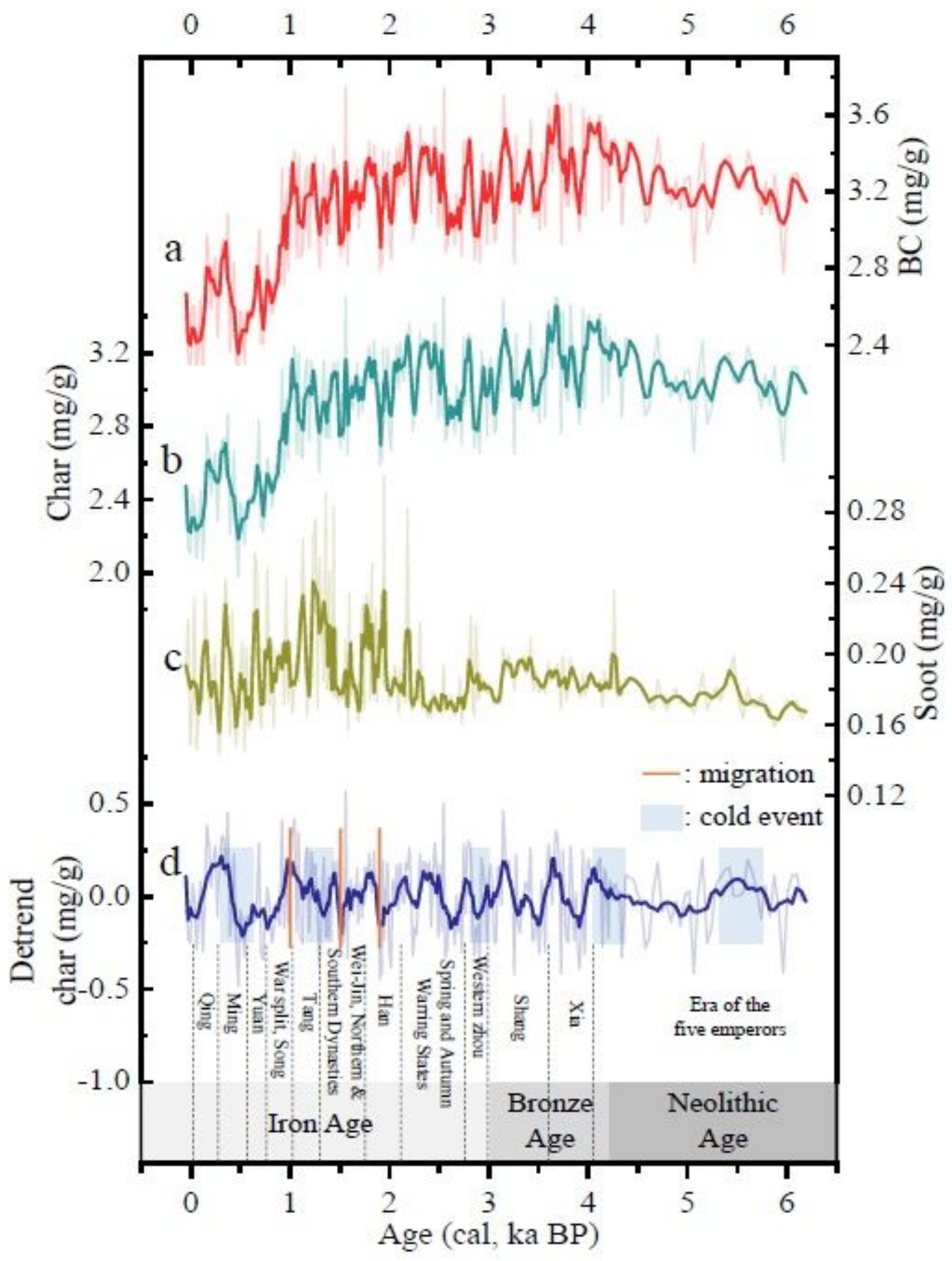

Figure 2

Sediment BC data for core ZY2 since 6.2 ka BP: the variation in (a) BC, (b) char, and (c) soot; (d) the char detrend with $50 \%$ loess regression (Fig. S1). Signal smoothing averaging three adjacent points for (a) to (c), and seven points for (d). 


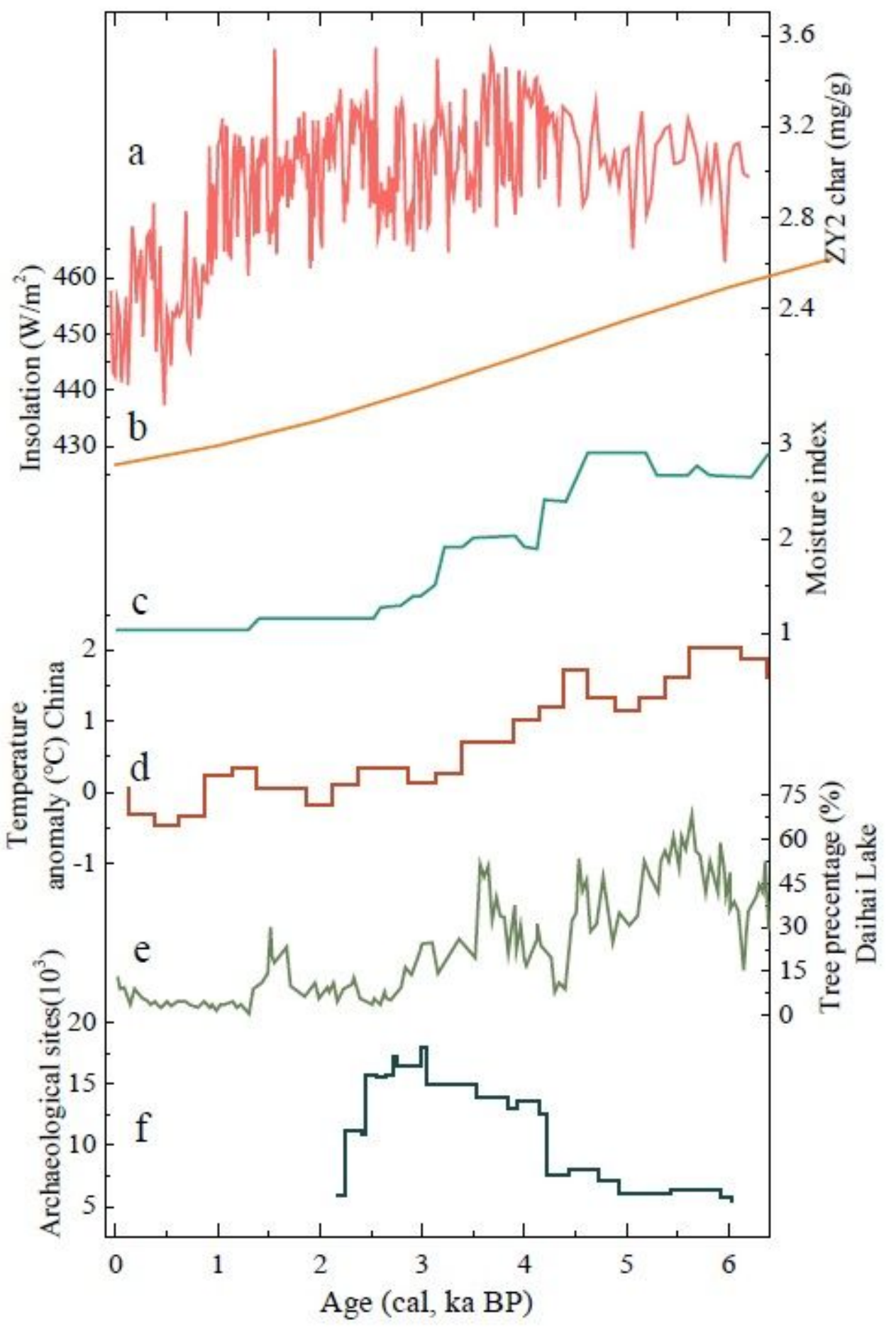

Figure 3

Comparison of the millennial-timescale variation in $B C$ records from $Z Y 2$ with other records since $6.2 \mathrm{ka}$ BP. (a) Fire activities recorded by char from core ZY2 in the SYS (this study); (b) extraterrestrial insolation of mid-month insolation 65N for July (33); (c) moisture index-based pollen in northern China (39); (d) temperature anomaly in China (38); (e) percentage of tree pollen recorded from the sediment core in Lake Daihai (40); (f) change in the total number of archaeological sites in northern China from 6 to 2 ka BP (50). 

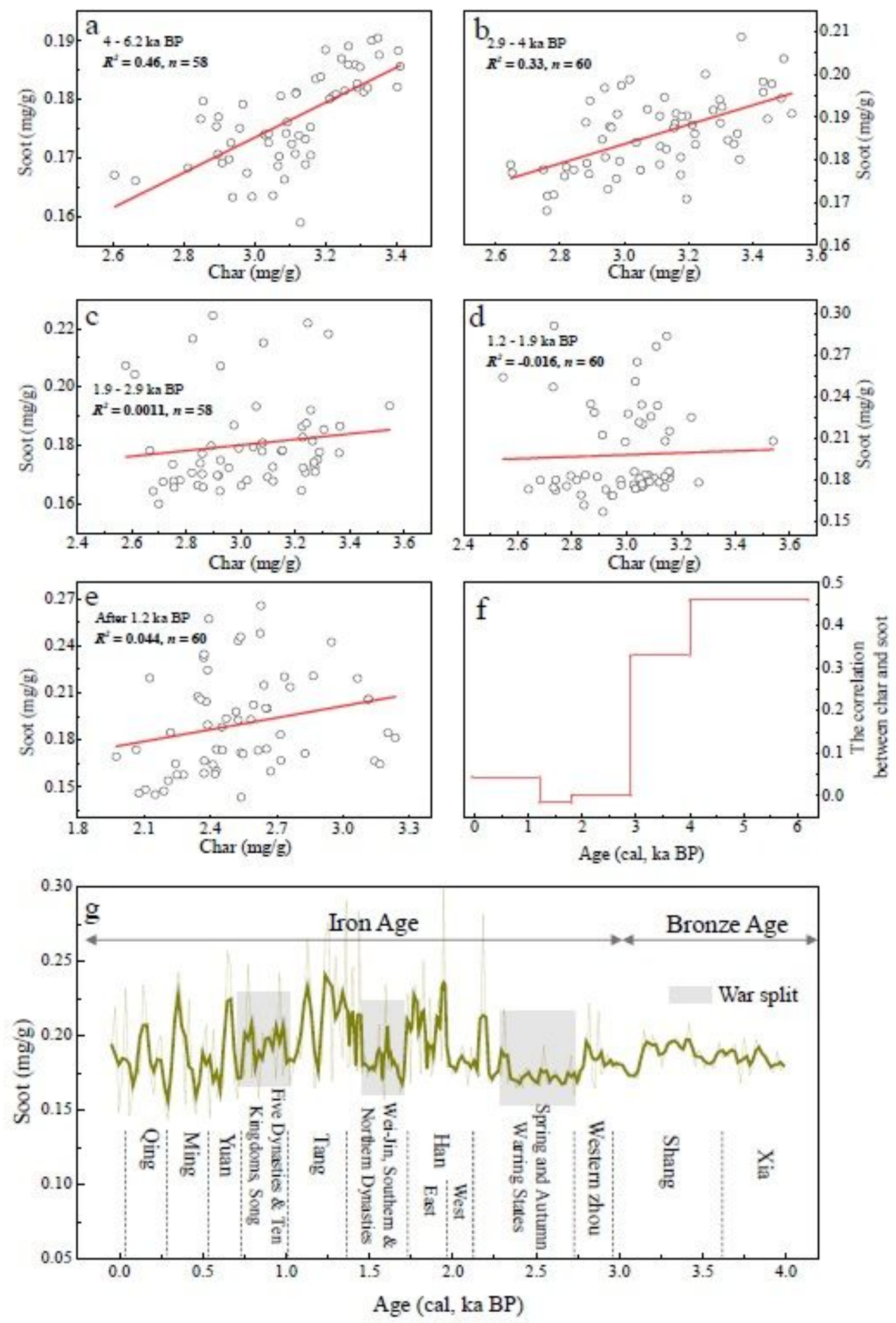

\section{Figure 4}

(a) to (e) show the correlations between char and soot at 0.05-1.2, 1.2-1.88, 1.88-2.9, 2.9-4, and, 4-6.2 ka BP, respectively. (f) Change in the correlation between char and soot since $\sim 6.2 \mathrm{ka} \mathrm{BP}$; (g) changes in soot from 0 to $4 \mathrm{ka}$ BP and the corresponding Chinese dynasties; signal smoothing was performed by averaging three adjacent points. 


\section{Supplementary Files}

This is a list of supplementary files associated with this preprint. Click to download.

- SupportingInformation.docx

- DatafileS1.xIsx 